\title{
ANALISIS PENYERAPAN TENAGA KERJA SEKTOR PARIWISATA DI JAWA BARAT
}

\author{
Andang Yoga Utama ${ }^{1}$; Rifki Khoirudin ${ }^{2}$ \\ Fakultas Ekonomi dan Bisnis Universitas Ahmad Dahlan \\ Jln. Kapas No. 9 Semaki, Umbulharjo, Yogyakarta \\ E-mail : andangyoga18@gmail.com \\ diterima: 29/1/2021; direvisi: 3/4/2021; diterbitkan: 26/9/2021
}

\begin{abstract}
This study aims to determine the impact of tourism in Jawa Barat on employment in the tourism sector from 2014 to 2018 . This study uses secondary data in the form of panel data in the province of Jawa Barat. The variables used are the number of tourist visits, hotels, restaurants and tourist objects. The results showed that tourist visits did not have a significant effect on employment in the tourism industry, hotels had no significant effect on emlpoyment in the tourism industry, restaurants had a positive and significant effect on empolyment in the tourism industry. In the tourism industry, tourist objects has a positive and significant impact. Absorbing labor in the tourism sector. The value of $\mathrm{R}^{2}$ in this study is 0.962321 , this means that the number of tourist visits, the number of hotels, the number of restaurants, and the number of tourist objects can explain the dependent variable of employment by $96.23 \%$, while $3.77 \%$ is explained by other variables outside the model.
\end{abstract}

Keywords: The number of tourist visits, the number of hotels, the number of restaurants, the number of tourism objects, and the employment of the tourism sector

\section{PENDAHULUAN}

Dalam perekonomian di negara berkembang seperti Indonesia, faktor penting yang tidak boleh dilupakan adalah penyerapan tenaga kerja yang mempunyai tujuan untuk menciptakan perekonomian yang kuat secara merata. Tersedianya kesempatan kerja untuk masyarakat sangat penting dan dibutuhkan untuk memecahkan masalah tersedianya kesempatan kerja yang terjadi hampir disetiap tahun. Menurut Akouino (2013) Pariwisata dinilai sebagai industri yang banyak menyerap tenaga kerja Indonesia. Sektor ini mempunyai peranan bagi perekonomian di Indonesia. Pariwisata juga memiliki peranan bagi pendapatan suatu daerah. Industri pariwisata di Indonesia berkembang sangat pesat dan berpotensi menambah lapangan kerja.Astina dkk, (2013). Pariwisata juga diharapkan bisa mendorong berbagai aspek kehidupan masyarakat di suatu daerah seperti sosial dan ekonomi masyarakat supaya bisa lebih baik lagi. Menurut Nursyamsi (2015) dengan dikembangkannya pariwisata di suatu wilayah, diharapkan berbanding lurus dengan jumlah kunjungan wisatawan yang meningkat,karena dengan kunjungan wisatawan yang meningkat merupakan gambaran keberhasilan pembangunan pariwisata di suatu wilayah, serta diharapkan dapat membuka sektor usaha baru yang dapat dimanfaatkan masyarakat sebagai contoh hasil pertanian, perkebunan, perikanan, peternakan,usaha penginapan maupun kerajinan yang merupakan dampak lanjutan dari pengeluaran uang yang dibelanjakan di daerah wisata tersebut, Aryunda (2011). Dampak lanjutan berkaitan dengan naiknya wisatawan yang datang diharapkan mampu membuat penyerapan tenaga kerja masyarakat di sektor pariwisata meningkat. Karena itulah, pariwisata harus didukung oleh sektor pendukung seperti infrastuktur maupun akomodasi bagi wisatawan dan pelayanan termasuk itu hotel, dan restoran.

Pariwisata berkaitan erat dengan beragam sarana dan prasarana yang disediakan baik itu dari pihak swasta, 
Jurnal Ilmiah Ekonomi dan Bisnis

Vol. 18. No.2,September 2021 : 147-155

EISSN : 2442 - 9813

ISSN : $1829-9822$

masyarakat, maupun pemerintah. Menurut Arianti (2014) pembangunan pada sektor pariwisata juga memiliki efek sehingga dengan dibangunnya obyek wisata dapat mempengaruhi struktur wilayah dimana kegiatan serta usaha dapat tertarik untuk berlokasi didekat obyek wisata tersebut. Oleh karena itu, pembangunan dan pengembangan pariwisata harus lebih ditingkatkan supaya penerimaan pendapatan dari sektor pariwisata lebih besar lagi, serta dengan tujuan lain yaitu mendorong pembangunan suatu daerah, memakmurkan dan mensejahterakan rakyat, serta menunjukkan kebudayaan daerah maupun nasional kepada para wisatawan. Berkembangnya pariwisata membawa dampak positif dengan kemungkinan munculnya industri industri baru yang muaranya akan membuka lapangan kerja bagi masyarakat.

Pengembangan pariwisata yang baik tentu dapat membuka lapangan kerja baru yang luas, seperti contoh disektor transportasi,akomodasi (hotel,penginapan, restoran/rumah makan) biro perjalanan dan agen wisata, pusat perbelanjaan, serta banyak tempat hiburan lainnya. Semakin lengkapnya sektor pendukung pariwisata, persentase wisatawan yang datang diharapkan juga naik, sehingga dapat menciptakan lapangan kerja bagi masyarakat dan meningkatkan peran masyarakat bagi perekonomian suatu daerah.

Dengan pengembangan pariwisata di suatu wilayah, diharapkan berbanding lurus dengan jumlah kunjungan wisatawan yang meningkat. Indonesia dengan kekayaan alam yang berlimpah serta keanekaragaman budaya disetiap daerah merupakan faktor yang sangat vital dan tidak bisa dipisahkan hubungannya dalam perkembangan dan pengembangan sektor pariwisata. Pariwisata juga diharapkan bisa mendorong berbagai aspek kehidupan masyarakat di suatu daerah seperti sosial dan ekonomi masyarakat supaya bisa lebih baik lagi
Potensi pariwisata, harus dikembangkan lebih baik lagi agar menjadi sektor andalan bagi suatu daerah maupun negara, karena pariwisata mampu memberikan peluang usaha yang sangat menjajikan dan lapangan pekerjaan bagi masyarakat.

Pengembangan pariwisata yang selama ini direncanakan baik dari pemerintah maupun swasta tentunya sudah memiliki target untuk meningkatkan jumlah wisatawan yang berkunjung karena dengan jumlah kunjungan wisatawan yang meningkat, maka pariwisata dapat menjadi pendapatan daerah yang cukup tinggi. Dampak lanjutan berkaitan dengan naiknya wisatawan yang datang diharapkan mampu membuat penyerapan tenaga kerja masyarakat di sektor pariwisata meningkat.

Provinsi Jawa Barat dengan ibukota Bandung merupakan wilayah yang sering menjadi tujuan wisata bagi wisatawan selain Provinsi Bali yang sudah terkenal lebih dahulu. Provinsi Jawa Barat dikenal dengan wisata alam yang masih asri serta obyek wisata lain yang potensial dan itulah kenapa daerah ini sering menjadi daerah tujuan wisata. Pada daerah ini sendiri terdapat beragam obyek wisata seperti wisata kuliner, alam, sejarah serta budaya.

Sejak tahun 2011, Pemprov Jawa Barat membentuk Badan Promosi Pariwisata Daerah untuk Provinsi Jawa Barat melalui Peraturan Gubernur No. 42 Tahun 2011. Hal ini bertujuan untuk lebih mempromosikan Pariwisata di Jawa Barat guna lebih meningkatkan perekonomian daerah dan kesejahteraan masyarakat. Selain itu, untuk memajukan sektor pariwisata juga tercantum dalam rencana pembangunan wisata (RIPPARPROV) periode 2015-2025. Pemprov Jawa Barat bertujuan untuk mewujudkan visi pembangunan kepariwisataan Jawa Barat sebagai destinasi wisata kelas dunia sesuai dengan rencana itu. Pariwisata perlu dikembangkan dan lebih dipromosikan karena dengan banyaknya potensi wisata di Jawa Barat tentu dapat membantu 
mensejahterakan rakyat itu sendiri dengan berbagai peluang yang ada. Salah satunya adalah potensi penyerapan tenaga kerja pariwisata dan sektor pendukung lainnya.

\section{TINJAUAN PUSTAKA}

Tenaga kerja merupakan seseorang dengan kemampuan memproduksi barang/jasa, dengan usia kerja 15 tahun 64 tahun. Tenaga kerja adalah satu dari banyak faktor penting dalam membangun ekonomi suatu negara, oleh karena itu peran tenaga kerja sangat penting bagi masyarakat. Tenaga kerja sangat berperan dalam proses produksi baik itu barang maupun jasa, Suparmoko (2002). Realita saat ini, keberadaan tenaga kerja perannya masih belum sepenuhnya bisa digantikan oleh teknologi. Oleh karena itu, tenaga kerja masih sangat dibutuhkan untuk mencukupi permintaan kebutuhan masyarakat tentunya dengan keterampilan dan keahlian sesuai dengan bidangnya masing masing.

Wisatawan menurut Soekadijo (2006) merupakan seseorang yang melakukan perjalanan dari rumah tanpa ada maksud untuk tinggal di tempat tujuan kunjungannya, dengan maksud hanya tinggal sementara di tempat tujuan yang didatangi. Sedangkan wisatawan menurut United Nation World Tourism (UNWTO), BPS (2020) merupakan seseorang atau kumpulan masyarakat yang melakukan aktivitas perjalanan ke wilayah diluar wilayah negara tempat tinggalnya, dengan jangka waktu kunjungan kurang dari 1 tahun dan mempunyai tujuan utama untuk berlibur atau tujuan lain.

Hotel menurut Marpaung, merupakan salah satu bentuk usaha yang memberikan jasa layanan makanan dan minuman, serta ruangan bagi masyarakat yang berkunjung dengan timbalbalik membayar tarif sesuai dengan fasilitas yang disediakan, Marpaung (2002). Hotel juga dibagi menjadi hotel berbintang dan hotel nonbintang. Hotel menjadi bagian yang tidak terpisahkan dari industri sektor pariwisata. Fungsi hotel juga untuk membantu menciptakan lapangan kerja bagi masyarakat. Hotel yang semakin menjamur di wilayah pariwisata juga mampu menyerap tenaga kerja yang kebutuhannya disesuaikan dengan manajemen hotel yang bersangkutan.

Menurut Suarthana (2006), restoran merupakan usaha dengan aktivitas kegiatan utamanya yaitu penyediaan dan layanan makanan serta minuman untuk masyarakat umum yang berkunjung di lokasi usahanya dengan tarif tertentu. Dalam rangka penyediaan dan pelayanan makanan serta minuman tentu dibutuhkan tenaga kerja yang jumlahnya memadai agar penyediaan dan pelayanannya kepada masyarakat dapat terpenuhi, oleh karena itu keberadaan restoran cukup penting bagi suatu daerah.

Menurut Marpaung, objek wisata merupakan gabungan dari hal-hal yang dapat membuat minat seseorang untuk datang ke tempat wisata tersebut meningkat. Aktifitas disini merupakan kegiatan yang mampu menarik minat wisatawan untuk melihat dan menikmati, serta fasilitas pendukung yang memadai serta menarik untuk dimanfaatkan wisatawan ketika berkunjung ke tempat tersebut, Untuk mengembangkan sektor pariwisata ini, maka potensi wisata yang ada harus dikembangkan sebaik mungkin agar minat para wisatawan untuk berwisata dapat meningkat, Marpaung (2002).

Pengunjung atau wisatawan adalah salah satu kunci dalam berkembangnya pariwisata di daerah. Kunjungan wisatawan yang tinggi pada suatu obyek wisata di daerah, maka pariwisata di daerah tersebut bisa terus berkembang. Austriana, (2005) menyatakan bahwa jika wisatawan berkunjung dengan waktu lebih lama pada daerah wisata, maka pengeluaran untuk kebutuhan konsumsi seperti akomodasi, makan, minum, transportasi, dll juga semakin banyak. Jika jumlah kunjungan wisatawan meningkat, minat investor untuk berinvestasi pada fasilitas pendukung pariwisata juga akan meningkat yang 
Jurnal Ilmiah Ekonomi dan Bisnis

Vol. 18. No.2,September 2021 : 147-155

EISSN : $2442-9813$

ISSN : 1829-9822

muaranya akan membuka lapangan kerja baru bagi masyarakat

Ramdhan (2017) menyatakan bahwa industri pariwisata khususnya di bidang perhotelan bersifat padat karya, memiliki pengaruh positif terhadap terciptanya kesempatan kerja. Perkembangan investasi saat ini pada sektor pariwisata seperti sarana akomodasi seperti hotel akan banyak membutuhkan tenaga kerja. Kriteria yang dibutuhkan adalah pekerja dengan keterampilan dan keahlian sesuai bidangnya. Dengan perkembangan hotel yang ada di daerah tujuan pariwisata maka terserapnya pekerja di sektor ini juga lebih meningkat.

Dengan perkembangan wisata saat ini tentu juga mendorong investasi di industri lain seperti halnya restoran. Restoran merupakan sarana pendukung serta sarana pemenuhan akomodasi bagi wisatawan yang datang di suatu daerah. Keberadaan restoran bukan hanya di lokasi wisata sangat penting bagi pengunjung atau wisatawan. Tidak dapat dipungkiri bahwa selain berwisata di obyek wisata, wisatawan juga sering menjatuhkan pilihannya untuk berwisata kuliner. Nuzulia (2018) menyatakan jika industri pariwisata membutuhkan tenaga kerja yang banyak, tidak hanya mesin saja. Keberadaan tenaga kerja sangat penting dalam rangka pemenuhan kebutuhan masyarakat, khususnya dalam hal ini pada sektor pariwisata. Restoran yang semakin berkembang jumlahnya pada setiap tahun tentu bisa membuka lapangan kerja baru bagi masyarakat, sehingga dengan semakin banyaknya restoran yang ada, jumlah pekerja yang dapat terserap akan bertambah.

Pariwisata merupakan sektor yang bersifat padat karya. Sektor pariwisata mempunyai peran penting untuk menciptakan kesempatan kerja yang lebih besar dan diharapkan dapat mengurangi pengangguran. Damardjati (2001) menyatakan bahwa pariwisata adalah gabungan bermacam macam sektor yang dapat menghasilkan produk ataupun jasa yang sangat dibutuhkan oleh wisatawan. Jika obyek wisata yang ada semakin bervariasi, maka peningkatan investasi dan minat wisatawan untuk berkunjung juga semakin tinggi. Perkembangan obyek wisata baru yang saat ini terjadi tentu bisa dimanfaatkan untuk membantu kesejahteraan masyarakat dan diharapkan mampu mengurangi pengangguran. Dengan berkembangnya obyek-obyek wisata maka kebutuhan tenaga kerja juga semakin meningkat, Taufik dan Rochaida (2011).

\section{METODE PENELITIAN}

Metode regresi yang digunakan adalah regresi linier berganda untuk meneliti pengaruh variabel independen terhadap variabel dependen dengan data panel untuk selanjutnya dilakukan analisis. Model persamaan ditulis :

$$
\begin{array}{ll}
\mathrm{Y}=\beta 0 & +\beta 1 \mathrm{X} 1+\beta 2 \mathrm{X} 2+\beta 3 \mathrm{X} 3+\beta 4 \mathrm{X} 4+\mathrm{e} \\
\mathrm{Y} & =\text { Penyerapan tenaga kerja } \\
\mathrm{X} 1 & =\text { Jumlah kunjungan wisatawan } \\
\mathrm{X} 2 & =\text { Jumlah hotel } \\
\mathrm{X} 3 & =\text { Jumlah restoran } \\
\mathrm{X} 4 & =\text { Jumlah obyek wisata } \\
& \text { Dalam data panel terdapat } 3 \text { macam }
\end{array}
$$
metode yaitu :

\section{Common Effect Model}

Dikenal dengan model paling sederhana, Karena metode ini menggabungkan data deret waktu dan individu. Berdasarkan hal tersebut, metode OLS dapat digunakan untuk estimasi data panel. Dimensi individu ataupun waktu dalam metode ini tidak diperhatikan, serta perilaku data antar obyek penelitian diasumsikan sama dalam rentang waktu tertentu.

\section{Fixed Effect Model}

Model FEM bisa digunakan untuk mengatasi kelemahan dari metode PLS/ CEM, karena slope dan intersep yang tidak berubah antara cross section dan time series. Variabel dummy juga bisa diestimasi menggunakan model ini. 


\section{Random Effect Model}

Model ini adalah cara estimasi dengan diasumsikan koefisien slope dan intersep yang memiliki perberbedaan antar individu dan antar waktu. Jika perbedaan antara individu dan waktu direfleksikan dengan intersep dalam metode FEM, maka dalam REM, perbedaan ini akan diselesaikan lewat error.

\section{Uji Chow}

Untuk memilih model CEM atau FEM mana yang sesuai untuk estimasi data panel, perlu dilakukan uji chow. Hipotesis :

\section{$\mathrm{H} 0=$ Common Effect Model \\ $\mathrm{H} 1=$ Fixed Effect Model}

Jika nilai prob. $>\mathrm{a}=0,05$ model terpilih adalah CEM. Namun jika nilai prob. $<\mathrm{a}=0,05$ maka $\mathrm{H} 0$ ditolak, sehingga Fixed Effect menjadi model terpilih.

\section{Uji Hausman}

Uji ini merupakan uji untuk menentukan model terbaik (REM atau FEM) untuk dipilih. Hipotesis :

\section{$\mathrm{H} 0=$ Random Effect Model \\ $\mathrm{H} 1=$ Fixed Effect Model}

Jika nilai prob $>\mathrm{a}=0,05$, maka model yang dipilih adalah Random effect. Sedangkan jika nilai prob $<\mathrm{a}=0,05$, maka model terbaik adalah Fixed Effect.

\section{Uji Koefisien Determinasi $\left(\mathbf{R}^{2}\right)$}

Pengujian ini dilakukan untuk melihat seberapa besar variabel dependen mampu dijelaskan oleh variabel independen. Jika nilai $\mathrm{R}^{2}$ mendekati 0 maka variabel dependen dijelaskan oleh variabel independen terbatas. Namun jika nilai $\mathrm{R}^{2}$ mendekati 1 maka variabel independen dapat digunakan untuk menjelaskan perubahan variabel dependen.

Uji F

Uji ini merupakan pengujian untuk mengetahui apakah variabel dependen dipengaruhi oleh variabel independen secara bersamaan. Hipotesis :
$\mathrm{H} 0=$ Variabel independen tidak mempengaruhi variabel dependen pada saat yang bersamaan (simultan)

$\mathrm{H} 1=$ Variabel independen tidak mempengaruhi variabel dependen pada saat yang bersamaan (Simultan)

Jika F hitung lebih besar dari $F$ tabel maka $\mathrm{H} 1$ diterima, dan dapat disimpulkan bahwa variabel independen berpengaruh signifikan terhadap variabel dependen secara simultan. Jika F hitung lebih kecil dari $\mathrm{F}$ tabel maka $\mathrm{H} 0$ diterima, maka dapat dipastikan bahwa variabel independen tidak berpengaruh signifikan terhadap variabel dependen secara bersamaan (Simultan) Uji Apriori

Uji Apriori adalah pengujian pada tanda dengan melihat dari persamaan hasil regresi. Uji apriori digunakan untuk mengetahui kecocokan antara hipotesis awal yang telah dibangun dengan hasil pengujian regresi.

Uji t

Pengujian dilakukan secara individu untuk mengetahui pengaruh variabel independen terhadap variabel dependen. Hipotesis :

$\mathrm{HO}=$ Variabel independen tidak mempengaruhi variabel dependen secara signifikan.

$\mathrm{H} 1=$ Variabel independen mempengaruhi variabel dependen secara signifikan.

Jika nilai prob. $\mathrm{T}$ hitung lebih besar dari 0,05, maka H0 diterima yang berarti variabel independen tidak berpengaruh signifikan terhadap variabel dependen. Namun jika nilai prob. $\mathrm{t}$ hitung lebih kecil dari 0,05 maka $\mathrm{H} 1$ diterima yang berarti variabel independen berpengaruh signifikan terhadap variabel dependen.

\section{HASIL DAN PEMBAHASAN Uji Chow}

\begin{tabular}{lccc}
\multicolumn{4}{c}{ Tabel 1. Uji Chow } \\
\hline Effects Test & Statistic & d.f. & Prob. \\
\hline Cross-sec. F & 33.643617 & $(26,104$ & 0.000 \\
& & ) & 0 \\
\hline
\end{tabular}

Sumber : Data diolah, 2020 
Jurnal Ilmiah Ekonomi dan Bísnis

Vol. 18. No.2,September 2021 : 147-155

EISSN : $2442-9813$

ISSN : $1829-9822$

Dari pengujian diperoleh nilai $\mathrm{F}$ statistik 33.643617 dengan probabilitas 0.0000. Probabilitas F statistik lebih kecil dari a $=0.05$ maka Fixed Effect Model adalah model terpilih.

\section{Uji Hausman}

Tabel 2. Uji Hausman

\begin{tabular}{lccc}
\hline Test Summary & $\begin{array}{c}\text { Chi-Sq. } \\
\text { Statistic }\end{array}$ & $\begin{array}{c}\text { Chi- } \\
\text { Sq. } \\
\text { d.f. }\end{array}$ & Prob. \\
\hline $\begin{array}{l}\text { Cross-sect. } \\
\text { random }\end{array}$ & 189.281211 & 4 & $\begin{array}{c}0.000 \\
0\end{array}$ \\
\hline
\end{tabular}

Sumber : Data diolah, 2020

Dilihat dari pengujian didapat chisquare 189.281211 dan probabilitas chisquare 0.0000 . Nilai prob. chi-square $0.0000<\alpha=0.05$, model terpilih pada uji hausman adalah Fixed Effect Model. Melalui kedua uji diatas, model terpilih yang digunakan adalah Fixed Effect Model.

\section{Uji Koefesien Determinasi $\mathbf{R}^{\mathbf{2}}$}

\begin{tabular}{cc}
\multicolumn{2}{c}{ Tabel 3. Uji R ${ }^{2}$} \\
\hline R-sq & 0.962321 \\
\hline Adj. R-sq & 0.951452 \\
\hline \multicolumn{3}{c}{ Sumber : Data diolah, 2020 } \\
Pada hasil regresi diatas, didapat
\end{tabular}
nilai R-squared 0.962321, maka diambil hasil bahwa variabel dependen dapat dijelaskan oleh variabel independen sebesar $96,23 \%$. Sisanya $3,77 \%$ dijelaskan oleh variabel selain model penelitian ini.

\section{Uji F Statistik}

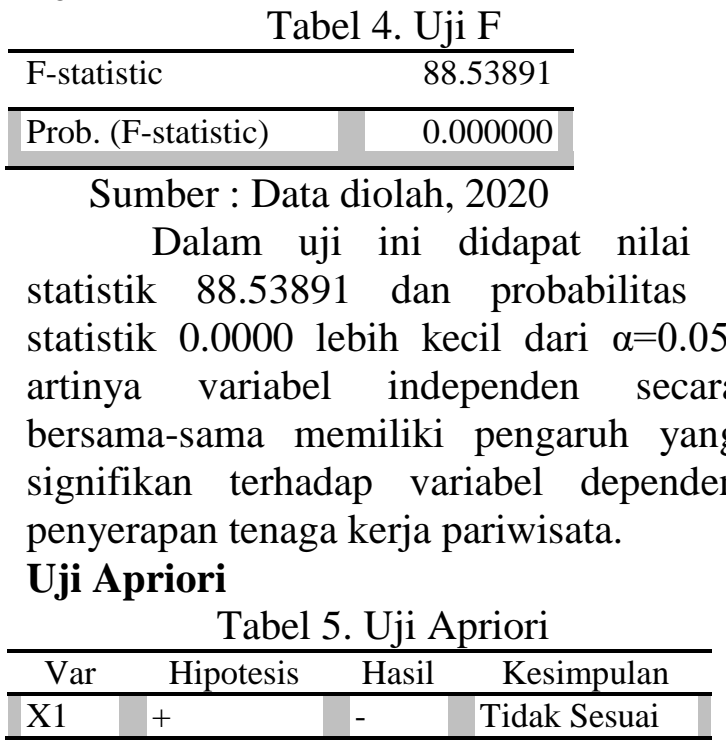

\begin{tabular}{llll}
\hline $\mathrm{X} 2$ & + & - & Tidak Sesuai \\
$\mathrm{X} 3$ & + & + & Sesuai \\
$\mathrm{X} 4$ & + & + & Sesuai \\
\hline
\end{tabular}

Sumber : Data diolah, 2020

Pada hasil pengujian, didapatkan hasil bahwa variabel jumlah kunjungan wisatawan dan jumlah hotel tidak sesuai dengan hipotesis awal.Variabel jumlah restoran dan jumlah obyek wisata pada hasil regresi bernilai positif, sehingga kedua variabel ini sesuai dengan hipotesis awal yang telah dibangun.

\section{Uji t Statistik}

\begin{tabular}{lcccl}
\multicolumn{5}{c}{ Tabel 6. Uji t } \\
\hline Var. & t-stat & t-tabel & Prob. & Ket. \\
\hline XI & 5.222831 & 1.97824 & 0.0000 & Tidak Sig. \\
X2 & 2.971873 & 1.97824 & 0.0037 & Tidak Sig. \\
X3 & 2.332394 & 1.97824 & 0.0216 & Sig. \\
X4 & 2.212067 & 1.97824 & 0.0291 & Sig. \\
\hline
\end{tabular}

Sumber : Data diolah, 2020

Pada pengujian diperoleh hasil bahwa tenaga kerja terserap di sektor pariwisata tidak dipengaruhi secara signifikan oleh jumlah wisawatan dan hotel, sedangkan penyerapan tenaga kerja di sektor pariwisata dipengaruhi secara signifikan oleh jumlah restoran dan objek wisata.

Penyerapan tenaga kerja di sektor pariwisata tidak dipengaruhi secara signifikan oleh kunjungan wisatawan. Ini menunjukkan walaupun ada peningkatan kunjungan wisatawan ke suatu destinasi wisata yang ada di Jawa Barat, tenaga kerja yang diperlukan tidak ikut meningkat atau bahkan tetap berdasarkan pekerja yang sudah ada, sehingga tenaga kerja yang terserap tidak menunjukkan peningkatan.

peningkatan jumlah kunjungan wisatawan juga tidak terjadi setiap hari melainkan hanya terjadi pada saat tertentu seperti musim liburan. Kunjungan pada hari biasa tidak sebanyak pada saat musim liburan sehingga walaupun ada peningkatan kunjungan wisatawan ke Provinsi Jawa Barat, tenaga kerja yang terserap tidak 
bertambah. Oleh karena peningkatan wisatawan yang hanya terjadi pada kondisi tertentu saja, tenaga kerja yang ada sudah mampu untuk melayani pengunjung yang datang.

Terserapnya tenaga kerja di sektor pariwisata tidak dipengaruhi secara signifikan oleh jumlah hotel. Dapat diartikan bahwa tenaga kerja yang terserap dalam sektor perhotelan ini tidak begitu besar. kemudian, dengan semakin berkembangnya akomodasi lain seperti penginapan, homestay,hotel kapsul, dan masih banyak lagi, semakin menambah pilihan bagi wisatawan untuk menginap.

Tidak dapat dipungkiri bahwa fasilitas hotel terbatas hanya kepada masyarakat yang mempunyai uang lebih untuk menginap di suatu daerah. Pada umumnya, wisatawan mencari tempat penginapan dengan pertimbangan biaya, maka dari itu pilihan selain hotel semakin banyak opsi bagi wisatawan. Selain itu, sebagian besar masyarakat yang mengunjungi suatu daerah untuk berwisata umumnya lebih memilih menginap di tempat yang dipandang lebih ekonomis. Lain halnya dengan wisatawan lokal Jawa Barat itu sendiri maupun disekitar, umumnya mereka hanya berwisata 1 hari saja, sehingga tidak memerlukan hotel maupun penginapan. Hal ini juga yang menyebabkan penyerapan tenaga kerja di sektor perhotelan ini tidak begitu besar, karena pertumbuhan hotel bintang dan nonbintang yang ada tidak begitu banyak.

Penyerapan tenaga kerja di sektor pariwisata dipengaruhi secara positif dan signifikan oleh jumlah restoran, dengan koefisien sebesar 3.785712 dan probabilitas $0.0216<\alpha=0.05$. Semakin meningkatnya jumlah restoran yang ada tentu kebutuhan tenaga kerja untuk melayani kebutuhan pengunjung yang datang juga ikut meningkat. Jumlah restoran yang ada pada tahun 2014-2017 terus mengalami peningkatan. Tentu dalam kenaikan restoran ini membutuhkan banyak tenaga kerja tambahan untuk memenuhi permintaan dalam sektor ini.

Perkembangan pariwisata yang sangat cepat saat ini tentu membuat wisatawan yang datang tertarik untuk berwisata kuliner. Indonesia memiliki kekayaan dalam berbagai jenis makanan, rasa, maupun penyajian yang khas sesuai daerah masing masing. Hal ini lah yang menyebabkan sebagian besar wisatawan senang untuk berwisata kuliner. Restoran juga tidak hanya terbatas menjual makanan saja, tetapi dengan suasana dan penyajian sesuai ciri khas daerah akan membuat wisatawan tertarik untuk berkunjung.

Industri kuliner juga memiliki peran dalam kemajuan wisata itu. Dengan meningkatnya wisatawan yang datang, tentu kunjungan ke restoran maupun rumah makan juga akan ikut meningkat.

Dengan semakin banyaknya wisatawan yang berkunjung ke daerah, maka kebutuhan pokok seperti makan dan minum umumnya juga akan meningkat. Hal inilah yang mendorong semakin berkembangnya restoran, dan dengan hal itu maka tenaga kerja yang dibutuhkan memang cukup besar. Sehingga dengan banyaknya lapangan pekerjaan yang tersedia, tenaga kerja yang terserap cukup besar. Dari industri kuliner khususnya restoran ini, diharapkan mampu membantu masyarakat dalam penyediaan lapangan kerja yang lebih besar lagi, serta membantu pemerintah dalam menangani masalah pengangguran yang dalam perkembangan setiap tahunnya selalu ada dalam jumlah besar.

Penyerapan tenaga kerja di sektor pariwisata dipengaruhi secara positif dan signifikan oleh jumlah obyek wisata, dengan probabilitas $0.0291<\alpha=0.05$ dan koefisien sebesar 7.322243. Berdasarkan data, jumlah obyek wisata yang ada pada Provinsi Jawa Barat terus meningkat setiap tahunnya. Dengan semakin banyaknya obyek wisata, maka tenaga kerja yang dibutuhkan dalam sektor ini juga meningkat. Sektor pariwisata sangat 
Jurnal Ilmiah Ekonomi dan Bisnis

Vol. 18. No.2,September 2021 : 147-155

EISSN : $2442-9813$

ISSN : $1829-9822$

penting untuk membuka kesempatan kerja yang lebih besar dan diharapkan dapat mengurangi pengangguran.

Dalam suatu obyek wisata, fasilitas sarana dan prasarana yang ada tentu membutuhkan pekerja untuk menggerakan dan mengelola obyek wisata tersebut dan untuk membantu wisatawan dalam berwisata secara aman dan nyaman. Hal inilah yang dapat dimanfaatkan untuk masyarakat dalam memperoleh pekerjaan, yang muaranya akan meningkatkan kesejahteraan masyarakat dan mengurangi tingkat kemiskinan. Obyek wisata dengan segala pendukung didalamnya perlu dikembangkan agar kemajuan ekonomi daerah dapat tercapai.

Jika obyek wisata yang ada semakin bervariasi, maka minat wisatawan untuk berkunjung juga semakin tinggi. Pilihan wisatawan untuk berwisata di Provinsi Jawa Barat juga dipastikan ikut meningkat, karena pilihan wisata tidak terbatas hanya pada 1 obyek wisata saja. Semakin banyak jumlah obyek wisata yang ada, maka banyaknya peluang pekerjaan yang dapat terserap juga akan semakin besar. Tingkat kesejahteraan masyarakat diharapkan juga meningkat, karena dengan banyaknya lowongan pekerjaan, pengangguran diharapkan dapat berkurang.

\section{KESIMPULAN DAN SARAN}

Kesimpulan dari penelitian yang telah dilakukan sebagai berikut :

1. Jumlah kunjungan wisatawan tidak berpengaruh signifikan terhadap terserapnya tenaga kerja di sektor pariwisata, dikarenakan peningkatan kunjungan wisatawan hanya terjadi pada kondisi tertentu, sehingga tenaga kerja yang terserap tidak bertambah.

2. Jumlah hotel tidak mempunyai pengaruh signifikan terhadap terserapnya tenaga kerja di sektor pariwisata. Hotel yang ada cenderung tetap, tidak mengalami banyak penambahan. Tenaga kerja yang dibutuhkan juga mempunyai kriteria tertentu sehingga penyerapan tenaga kerja pada hotel tidak begitu besar.

3. Jumlah restoran berpengaruh secara signifikan terhadap terserapnya tenaga kerja di sektor pariwisata. Restoran yang ada terus mengalami kenaikan sehingga tenaga kerja yang terserap cukup besar.

4. Jumlah obyek wisata berpengaruh signifikan terhadap terserapnya tenaga kerja di sektor pariwisata. Obyek wisata yang ada terus bertambah sehingga kebutuhan tenaga kerja juga ikut meningkat.

Potensi alam maupun budaya yang beragam dapat dikembangkan untuk menarik minat pengunjung. Dengan semakin bertambah dan berkembangnya obyek wisata yang menarik, diharapkan banyak wisatawan yang berkunjung dan kesempatan kerja bagi masyarakat yang tercipta juga semakin luas.

Pemerintah daerah sebaiknya meningkatkan pembangunan kawasan wisata, khususnya infrastuktur pendukung seperti akses jalan dan fasilitas di obyek wisata agar wisatawan yang akan berkunjung merasa nyaman, serta meningkatkan keamanan wilayah agar wisatawan yang berkunjung maupun investor yang akan berinvestasi merasa aman untuk membuka usaha baru yang muaranya akan membuka lapangan kerja baru bagi masyarakat.

\section{DAFTAR PUSTAKA}

Akouino, C. (2013) 'Analisis Penyerapan Tenaga Kerja Sektor Pariwisata (Sektor Perdagangan, Hotel Dan Restoran) Di Kota Batu'. Jurnal Ekonomi Pembangunan, 11(2), pp. 153-167.

Arianti, D. (2014) 'Pengaruh Sektor Pariwisata Terhadap

Perekonomian dan Keruangan Kota Bukittinggi (Pendekatan 
Analisis Input Output)'. Jurnal Wilayah \& Lingkungan, 2(3), pp. 183-196.

Aryunda, H. (2011) 'Dampak Ekonomi Pengembangan Kawasan Ekowisata Kepulauan Seribu'. Journal of Regional and City Planning, 22(1), pp. 1-16.

Astina, C., Hamzah, A. dan Nasir, M. (2013) 'Pengaruh Pariwisata Terhadap Penyerapan Tenaga Kerja Di Provinsi Aceh'. Jurnal Ilmu Ekonomi, 1(4), pp. 14-24.

Austriana, I. (2005) 'Analisis Faktor yang mempengaruhi Penerimaan Daerah dari Sektor Pariwisata di Jawa Tengah'. Skripsi. Universitas Diponegoro.

BPS (2020) 'Pariwisata'. Available at: https://www.bps.go.id/subject/16/ pariwisata.html.

Damardjati， R. S. (2001) Istilah-Istilah Dunia Pariwisata. Jakarta: Pradya Paramita.

Marpaung, H. (2002) Pengetahuan Kepariwisataan. Bandung: Alfabeta.

Muhammad Taufik, Eny Rochaida, F. (2011) 'Pengaruh Investasi Dan Ekspor Terhadap Pertumbuhan Ekonomi Serta Penyerapan Tenaga Kerja Provinsi Kalimantan Timur'. Jurnal Ekonomi Kuantitatif Terapan. 7(2), pp. 83-198.

Nursyamsi, S. (2015) 'Hubungan Kausalitas Antara Jumlah Kunjungan Wisatawan Dan Produk Domestik Regional Bruto (PDRB) Sulawesi Selatan'.Jurnal Ilmiah Mahasiswa FEB Universitas Brawijaya 3(2), pp. 1-9.

Nuzulia, M. A. (2018) 'Strategi Pengembangan Sektor Pariwisata Kawasan Istano Basa Pagaruyung Di Kabupaten Tanah Datar Menuju Destinasi Wisata Halal'. Skripsi.
Universitas

Yogyakarta.

Muhammadiyah

Pergub Jabar No : 42 Tahun 2011.

Ramdhan, M. (2017) 'Analisis Penyerapan

Tenaga Kerja Pada Sektor

Pariwisata di Kabupaten/Kota

Daerah Istimewa Yogyakarta'.

Skripsi. Universitas Islam Indonesia.

Rencana Induk Pembangunan Kepariwisataan Provinsi Jawa Barat Tahun 2015-2025.

Soekadijo, R. . (2006) Anatomi pariwisata: memahami pariwisata sebagai 'systemic linkage'. Jakarta: Gramedia Pustaka Utama.

Suarthana (2006) Manajemen Perhotelan edisi Kantor Depan. Kuta Utara: Mapindo.

Suparmoko, M. (2002) Ekonomi Publik, Untuk Keuangan dan Pembangunan Daerah. Yogyakarta: Andi Ofset. 